\title{
Efficacy of Biopesticides and Leaf Removal in Grapevine Powdery Mildew Management
}

\begin{abstract}
Michelle M. Moyer, Assistant Professor, Department of Horticulture; Jensena M. Newhouse, Research Technician, Department of Horticulture; and Gary G. Grove, Professor, Department of Plant Pathology; Washington State University Irrigated Agriculture Research and Extension Center, Prosser 99350
\end{abstract}

Accepted for publication 11 April 2016. Published 20 April 2016.

\section{ABSTRACT}

Moyer, M. M., Newhouse, J. M., and Grove, G. G. 2016. Efficacy of biopesticides and leaf removal in grapevine powdery mildew management. Plant Health Prog. 17:84-91.

Integrating biological-based fungicides into conventional spray programs may help with fungicide resistance management. However, little is known about how to best integrate these products while still maintaining maximum disease control. Programs with as few as one synthetic fungicide or as many as three synthetic fungicides added to a biopesticide-based rotation during the bloom period of Vitis vinifera had significantly better disease control than a biopesticide-only-based program. When integrated with different timings of fruit-zone leaf

\section{INTRODUCTION}

In the inland Pacific Northwest of the United States, grapevine powdery mildew (Erysiphe necator) is the leading cause for fungicide use on wine grapes (Vitis vinifera). While the normally dry, warm growing season conditions result in reduced fungicide use relative to other grape-growing regions nationally and internationally (Moyer and O'Neal 2014), there is still a need for multiple annual sprays to maintain a marketable crop. With an increased demand for sustainable and/or "low-input" production systems, many growers are considering integrating biopesticides into their management programs (Copping and Menn 2000), and specialty crop producers such as those of wine grapes are no exception. In addition, using biopesticides is seen as a potentially viable option (Jacobsen et al. 2004) for aiding in fungicide rotations necessary to reduce the risk of resistance development. This perception is likely due to their lack of either specific classification by the Fungicide Resistance Action Committee (FRAC), or the inherent low risk of resistance development due to multiple modes of activity.

Biopesticides, however, do have an uneven history of efficacy on $V$. vinifera and hybrid wine grapes, dependent on location, weather, target disease, and other products present in fungicide rotations (Leavitt and Martin-Divall 2005; Schilder et al. 2010; Wilcox and Riegel 2010; Wilcox and Riegel 2012). This lack of consistent response in disease management has resulted in a cautious approach to using these products as a sole means of control and may be a key limiting factor to their widespread adoption as a part of conventional management programs or to an expansion of their use in organic management programs. Could

Corresponding author: Michelle Moyer. Email: michelle.moyer@wsu.edu.

doi:10.1094/PHP-RS-16-0009

(C) 2016 The American Phytopathological Society removal, specific combinations of biopesticide programs and fruit-zone leaf removal enhanced the efficacy of that program to be on par with disease control seen in a program entirely based on synthetic fungicides. This suggests that when designing a fungicide program using biopesticides as a base, the addition of a synthetic fungicide during the window of ontogenic susceptibility in clusters and the adoption of cultural practices such as leaf removal can significantly improve the efficacy of that program.

the efficacy of control programs that incorporate biopesticides be improved with more strategic timing of the use of these products relative to the use of other products in a fungicide rotation? Would cultural practices in the vineyard such as fruit-zone leaf removal improve the overall efficacy of a program that is predominately biopesticide-based? The $V$. vinifera-E. necator interaction is an ideal pathosystem to assess these impacts, as the final outcome of disease severity is temporally limited to a defined susceptibility period for fruit around bloom (Gadoury et al. 2002). This temporal window allows for a targeted focus on timing of different products and cultural practices, potentially enhancing their efficacy, and ultimately allowing for products of different activity to be used during periods that are less critical to final disease outcome but of equal importance when considering fungicide activity rotation for resistance management.

This study focused on providing a more refined guideline as to the best timing and frequency for integrating biopesticides into conventional powdery mildew management programs while still maintaining acceptable levels of disease control. The use of cultural practices (i.e., fruit-zone leaf removal) to enhance biopesticide activity was also evaluated.

\section{BIOPESTICIDE-BASED PROGRAM EFFICACY IN A VINEYARD SETTING}

In 2013, experiments were conducted at the Washington State University-Irrigated Agriculture Research and Extension Center's (IAREC) Headquarters Research farm $\left(46.25^{\circ} \mathrm{N} ; 119.73^{\circ} \mathrm{W}\right)$. The 1-ha vineyard was planted in 2009 to own-rooted Vitis vinifera 'Chardonnay.' Due to the young age of this vineyard, overall vine canopy size and disease pressure were low. In 2014, experiments were conducted at WSU-IAREC's Roza Research Farm $\left(46.29^{\circ} \mathrm{N} ; 119.73^{\circ} \mathrm{W}\right)$. The vineyard at that location is a 1ha mixed-planting of own-rooted $V$. vinifera 'Chardonnay' and 'Riesling' planted in 2001. In this vineyard, the vine canopies 
were larger due to the vineyard age, and there was overall higher disease pressure due to the longer period for natural inoculum build-up. Only Chardonnay vines were used for the experiment. In both vineyards, border rows remained unsprayed from the onset of vineyard planting to provide a natural reservoir of inoculum. No inoculum was artificially introduced into the vineyard for the experiments described herein. In both locations, vines were planted on a $1.8 \times 2.7 \mathrm{~m}$ (vine $\times$ row) spacing, with north-south row orientation. Vines were trellised on a modified vertical shoot position system, with a single set of adjustable foliar catch wires located approximately $15 \mathrm{~cm}$ above the fruiting wire which were moved upward as the vine canopy developed (typically moved in mid-June). Vines were trained to a dual-trunk bilateral cordon and were spur-pruned. Both vineyards were dripirrigated, with a 40-cm weed-free strip maintained directly under vines and natural vegetation between the rows maintained through routine mowing.

Weather data was collected using the Washington State University's AgWeatherNet system (http://weather.wsu.edu). In 2013, the WSU-HQ weather station was used and is located approximately $500 \mathrm{~m}$ from the experimental vineyard. In 2014, the Roza weather station was used, and is located $3 \mathrm{~m}$ from the outside edge of the experimental vineyard. Daily maximum and minimum air temperatures and daily total precipitation for 2013 and 2014 are presented in Figure 1. Both 2013 and 2014 were considered average to slightly above average (respectively) in terms of temperature, and average to below average (respectively) for powdery mildew disease pressure. This average to low disease pressure was due to lack of summer precipitation, low overall relative humidity, high solar radiation, and several in-season high temperature events (Austin and Wilcox 2012; Carroll and Wilcox 2003; Choudhury et al. 2014; Moyer et al. 2016).

Specific fungicide treatments and application timing are listed in Table 1. Fungicide treatment replicate plots consisted of six vine panels; data were collected from the center four vines. Individual fungicide treatments were replicated three times in a randomized block design. Treatments were applied using a modified Rears sprayer with a custom-built boom equipped with seven flat spray nozzles (TeeJet 800; TeeJet Nozzles, Springfield, IL) at 100 psi. The sprayer consisted of three tanks: two 95-liter tanks and one 189-liter tank. Tractor speed was 3.2 to $4.8 \mathrm{~km} / \mathrm{h}$. Total water volume applied changed with the developing canopy over the course of each growing season. Total water volume during the first spray of the season was applied using three nozzles resulting in 420 liters/ha, The second spray was applied using five nozzles resulting in 701 liters/ha; the remaining sprays were applied using seven nozzles at 982 liters/ha. Regardless of total water volume applied, the product rate consisted of the following per-hectare equivalents: $8.97 \mathrm{~kg}$ sulfur (Microthiol Disperss, United Phosphorus Limited, Cedex, France); 7.02 liters extract of Reynoutria sachalinensis (Regalia, Marrone Bio Innovations, Davis, CA); 7.02 liters suspended Bacillius pumilus (Sonata, Bayer Crop Science, Raleigh, NC); $365.6 \mathrm{ml}$ fluopyram (Luna Privilege, Bayer Crop Science, Raleigh, NC); and $292.2 \mathrm{ml}$ quinoxyfen (Quintec, Dow AgroSciences, Indianapolis, IN). All synthetic treatments were applied with a surfactant (Break-Thru, Evonik Industries, Essen, Germany) at $236.6 \mathrm{ml}$. Control treatments received no sprays. Disease evaluation was as described below.

Fungicides were selected based on general industry acceptance (Moyer and O'Neal 2014) and regional product availability. There was specific interest in including a plant-based biopesticide (Reynoutria sachalinensis), a microbe-based biopesticide (Bacillius pumilus), and a common contact product (sulfur). The two synthetics (fluopyram and quinoxyfen) were chosen based on their increased use and popularity in the industry. While fungicides in FRAC groups 3 and 11 (Anonymous 2016) still remain the more common fungicides used in area programs, research priorities for the region emphasized fungicide resistance management (Moyer and O'Neal 2014). Fluopyram is a FRAC 7 fungicide and quinoxyfen is a FRAC 13 fungicide.

Fruit-zone leaf removal treatments were nested within each fungicide treatment replicate described above. Of the four center data vines in each fungicide treatment replicate plot, one vine was dedicated to each leaf removal treatment. As with fungicide treatments, leaf removal within each fungicide treatment was replicated three times. Fruit-zone leaf removal consisted of removing all leaves on a shoot from the base of the shoot up and adjacent to the secondary cluster, on all shoots in a canopy. Fruitzone leaf removal treatments consisted of a control (no leaf removal), prebloom (when $50 \%$ of the clusters were at rachis elongation), bloom (when $50 \%$ of the clusters were at $50 \%$ capfall), and 4 weeks postbloom. In 2013, leaf removal treatments were implemented on 16 May (prebloom), 3 June (bloom), and 5 July (4 weeks postbloom). In 2014, leaf removal treatments were implemented on 28 May (prebloom), 16 June (bloom), and 11 July (4 weeks postbloom).

All statistical analyses were completed in JMP 9 (SAS Institute, Cary, NC), using analysis of variance (ANOVA) and the generalized linear model (GLM) platforms. Means separation was done using Tukey's HSD at $\alpha=0.05$. Disease severity data were $\log$ transformed prior to analysis to adjust for non-normal distribution.

\section{INFLUENCE OF LEAF REMOVAL ON SPRAY COVERAGE}

Spray coverage was evaluated in the leaf removal treatments using water-sensitive cards (Syngenta Crop Protection AG, Basel, Switzerland). Cards were affixed to the node between the basal and secondary clusters using a clothespin, water-sensitive side facing east. The cards were placed in the vineyard just prior to spraying, and then removed promptly after they had dried in the field (approximately 2 to $3 \mathrm{~h}$ ). Four cards were placed in each leaf removal subplot in only one fungicide treatment in both 2013 and 2014 (four replicates of each fungicide treatment), as the fungicide type was not a factor in this coverage assessment. Coverage was estimated on each card using open-source ImageJ software that calculates pixel areas using color thresholds (Abramoff et al. 2004). Spray coverage was assessed on 12 June, 27 June, and 6 August in 2013, and 10 June, 24 June, and 5 August in 2014.

In 2013, prebloom leaf removal did not improve spray coverage relative to the control treatment early in the season, but did improve coverage relative to the postbloom treatment (which, in effect, was the same as the control at this time) (Fig. 2A). This was likely due to the variability in canopy density early in the season in the young vineyard. In the spray assessment after the bloom leaf removal treatment, both the prebloom and bloom leaf removal treatments had significantly higher coverage than the control. As expected, the bloom treatment also had significantly higher coverage than the postbloom treatment (Fig. 2B). At this assessment date, 27 June 2013, the vine canopy had reached nearmature density for the vineyard for that growing season. In the final assessment of the season, which occurred 32 days after the postbloom leaf removal, no differences in spray coverage were seen (Fig. 2C) likely due to canopy refill (i.e., the development of summer lateral shoots which commonly occurs postbloom in eastern Washington). 

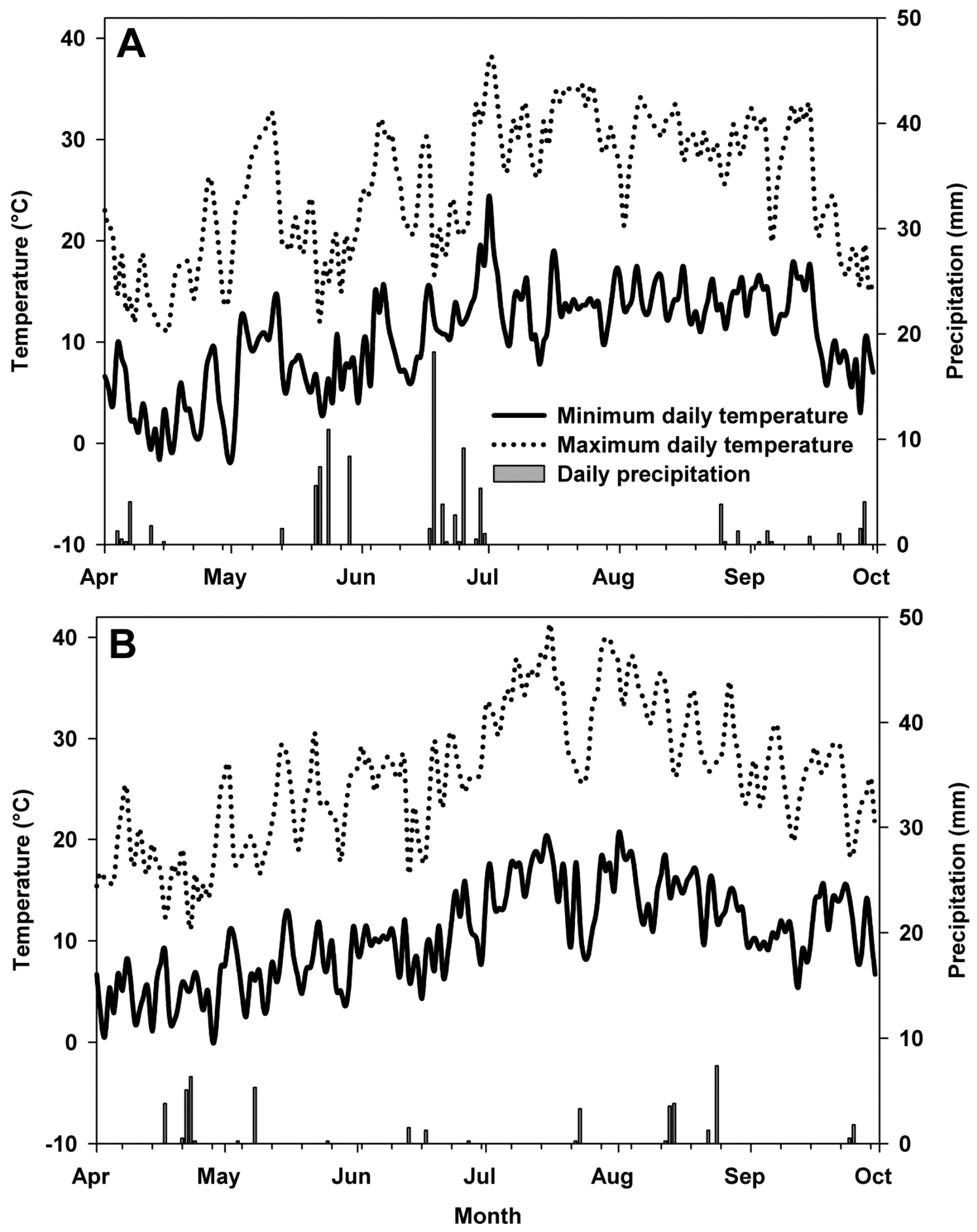

\section{FIGURE 1}

Daily maximum and minimum temperature and daily precipitation for 1 April to 30 September in both 2013 (A) and 2014 (B) as reported by AgWeatherNet (http://weather.wsu.edu) for WSU-HQ and ROZA weather stations, respectively. The 2013 growing season was marked by average temperatures and above-average June precipitation, whereas 2014 was marked by above average temperatures and below-average spring precipitation. The 2013 growing season was characterized as an "average" vintage, whereas 2014 was characterized as "warm" and early, with respect to typical fruit harvest dates. The 2013 and 2014 growing seasons were average to low-pressure (respectively) for grapevine powdery mildew. 


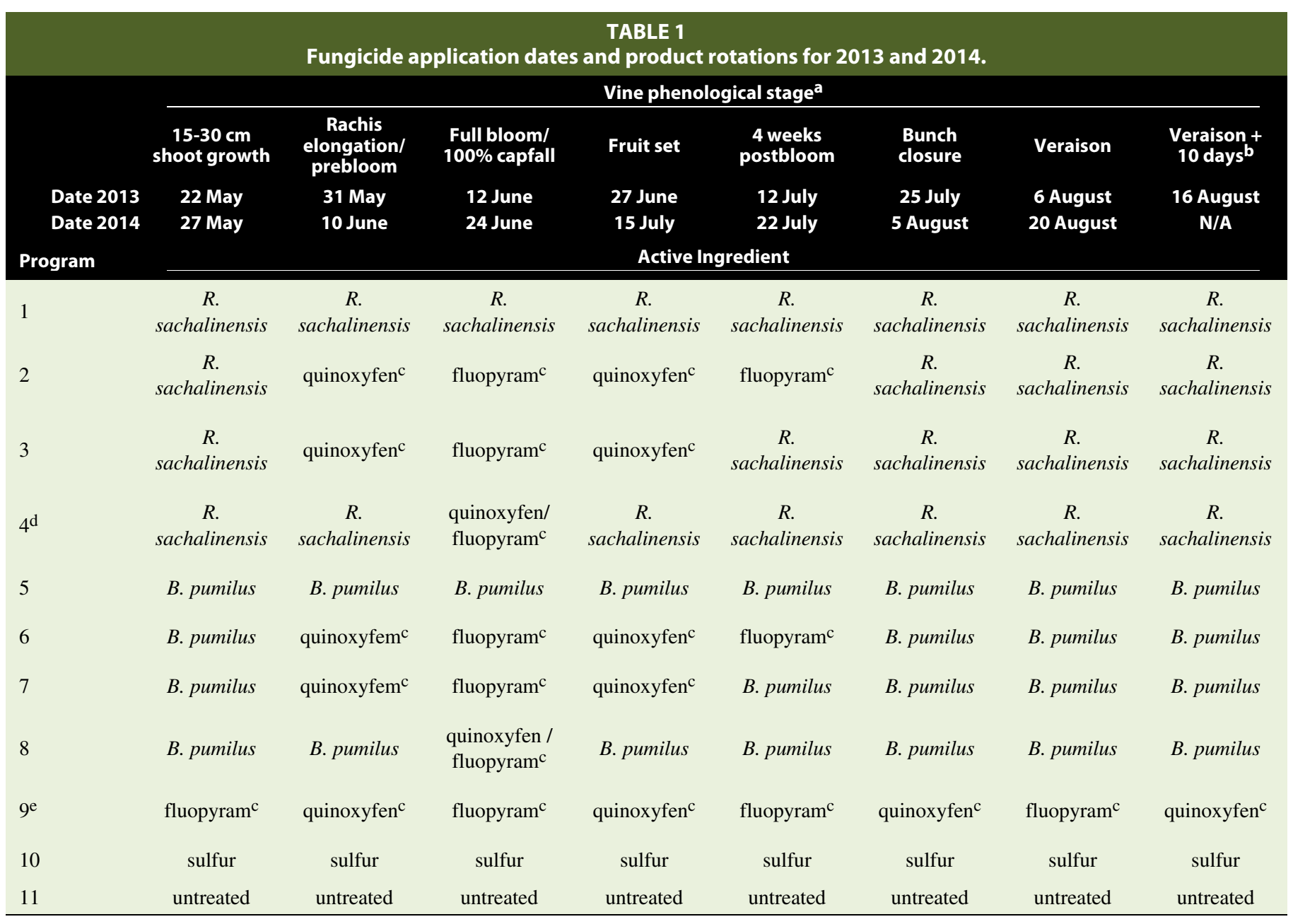

a Key phenological dates of vine development: budbreak, 27 April 2013 and 17 April 2014; bloom (50\% of clusters at 50\% capfall), 3 June 2013 and

13 June 2014; véraison (50\% of clusters at 50\% softening), 4 August 2013 and 14 August 2014.

b Application timing in 2013 only.

${ }^{\text {c }}$ Synthetic fungicides were applied with Break-Thru surfactant.

${ }^{\mathrm{d}}$ In 2013, the synthetic fungicide used was quinoxyfen; in 2014, it was fluopyram.

${ }^{\mathrm{e}}$ This fungicide program is not recommended for commercial production practices due to risk for fungicide resistance development. Always follow

label instructions regarding fungicide group rotations.

In 2014, the prebloom leaf removal significantly improved coverage relative to the control, but was not different from the bloom and postbloom treatments. The bloom and postbloom leaf removal treatments did not have significantly different coverage from the control (Fig. 2D). The higher variability in coverage response on this date is likely due to variable canopy development which is common early in the season, even in vineyards that are well established, such as that used in 2014 relative to 2013. At the end of June 2014, when both the prebloom and bloom leaf removal had been completed, the prebloom still had significantly higher coverage than the control, but also had significantly higher coverage than the postbloom (Fig. 2E). However, the bloom leaf removal treatment which was implemented only 8 days earlier, was neither different from the prebloom, nor different than the control/postbloom coverage. At the end of the growing season, after all leaf removal treatments had been implemented in 2014, the bloom treatment had significantly higher coverage than the control, despite the fact that the postbloom leaf removal treatment had been the most recent timing for leaf removal. The postbloom and prebloom leaf removal treatments were intermediary to the control and bloom treatment (Fig. 2F).

In all cases, the assessments of coverage occurred between 8 and 32 days after the respective leaf removal treatments. Given this duration between cultural practice implementation and spray coverage assessment, and given the nature of vine growth and development, one can hypothesize that an even greater increase in coverage would be seen if spray applications occurred directly after the implementation of leaf removal, with the greatest impact in terms of improved coverage during the critical window of disease development (i.e., bloom to 4 weeks postbloom) (Gadoury et al. 2003) from prebloom or bloom leaf removal (Fig. 2). However, one must be cautions that leaf removal does not occur immediately after the application of a contact product, as that would result in removal of product from the system, and prolonged exposure of clusters which may have reduced to no pesticide coverage due to foliar blocking of sprays, thus increasing their risk of infection.

\section{INFLUENCE OF BIOPESTICIDES AND LEAF REMOVAL ON DISEASE CONTROL}

Powdery mildew (E. necator) ratings were collected by visually estimating percent surface area of the cluster displaying symptoms. For each fungicide program + leaf removal treatment replicate, 5 clusters were repeatedly and non-destructively visually rated between 2 and 6 times from early July until midSeptember; however only final disease severity is reported. 


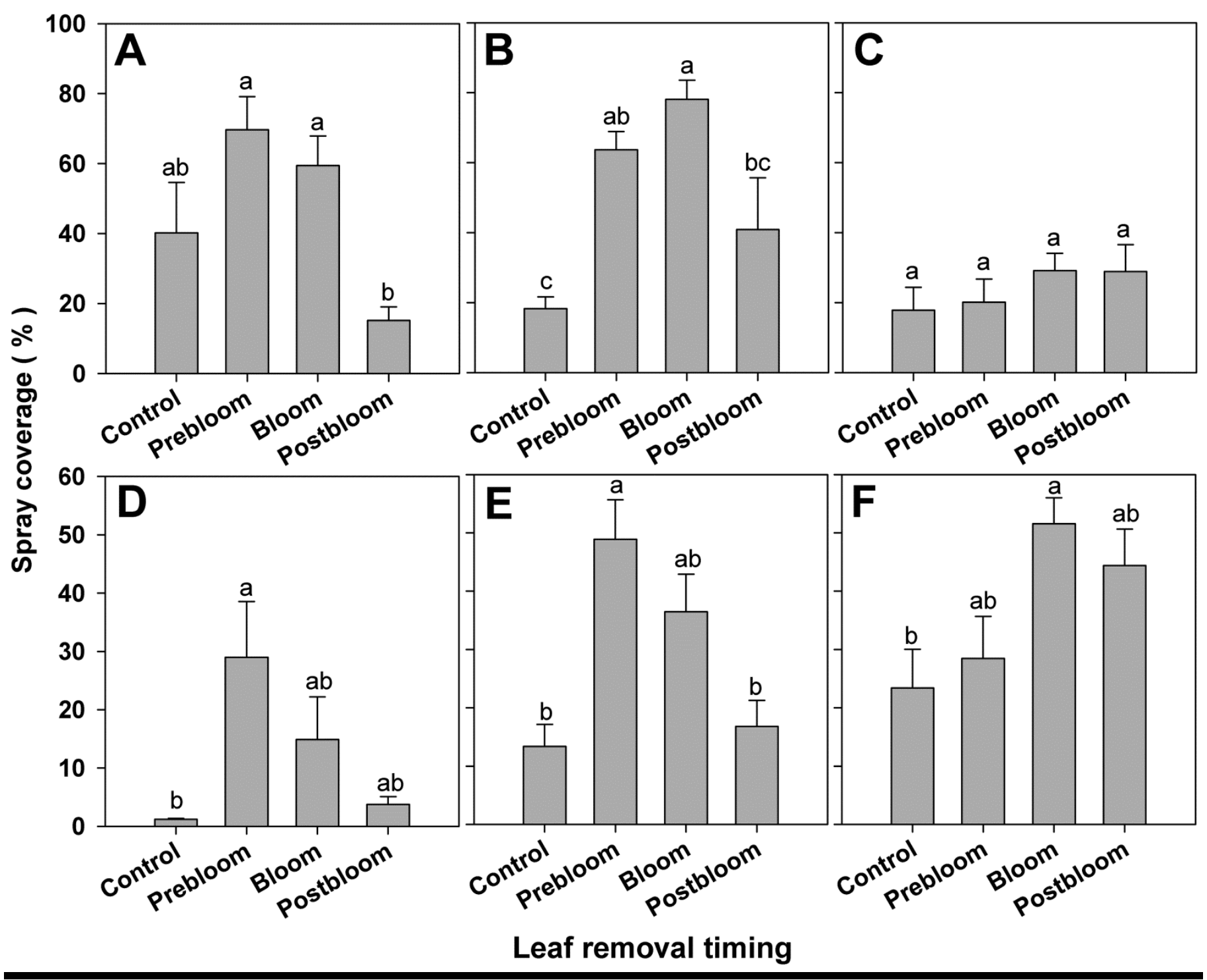

FIGURE 2

Spray coverage as assessed by percent area covered using water sensitive paper and ImageJ analysis on: (A) 12 June 2013, 15 days after prebloom leaf removal; (B) 27 June 2013, 24 days after bloom leaf removal; (C) 6 August 2013, 32 days after postbloom leaf removal; (D) 10 June 2014,13 days after prebloom leaf removal; (E) 24 June 2014, 8 days after bloom leaf removal treatment; and (F) 5 August 2014, 20 days after postbloom leaf removal. Three replicate cards were used per treatment. Means separated using Tukey's HSD at $a=0.05$.

Fungicide programs significantly influenced final disease severity $(P<0.0001$ for both 2013 and 2014) (Fig. 3). When looking solely at the effects of leaf removal, the timing of leaf removal did not affect disease severity in $2013(P=0.11)$, but the simple act of removing leaves relative to doing nothing at all significantly reduced disease severity in $2014(P=0.01)$.

In 2013, an average disease-pressure year, in the lower diseasepressure vineyard, a $R$. sachalinensis-based program with at least three synthetic fungicide applications around bloom performed equally well compared to a season-long synthetic program (eight total applications) (Fig. 3A). In a B. pumilus-based program, four synthetic fungicide applications were required to match that of a season-long synthetic fungicide program. Interestingly, in 2013, the unsprayed control (\#11) had significantly less disease severity than the sulfur control (\#10) and the B. pumilus-only (\#5) programs (Fig. 3A). This higher disease level in the sulfurtreatment could be due to the variable nature of disease distribution in the young vineyard, and by temporary increases in canopy moisture from the water carrier that would be more favorable for disease development (Carroll and Wilcox 2003). While sulfur will volatilize, coverage is still necessary for adequate disease control, and poor coverage may be attributed to windy conditions common in eastern Washington early in the growing season.

Fungicide program efficacy in 2014 was more straightforward. Overall disease levels were higher in this vineyard despite the environmental conditions being less favorable. This is owing to the block used in 2014 being older and having a longer history of disease development. In 2014, the biopesticide-only programs had the same level of disease as the unsprayed control and the sulfuronly control (Fig. 3B). While none of the biologically-based programs met the same level of disease control as a synthetic-only program, almost all biopesticide programs with at least one synthetic product around bloom out-performed a biopesticideonly program (seven total applications). In fact, one application of fluopyram at full bloom provided control equal to three applications of alternating quinoxyfen and fluopyram from rachis elongation to fruit set. 

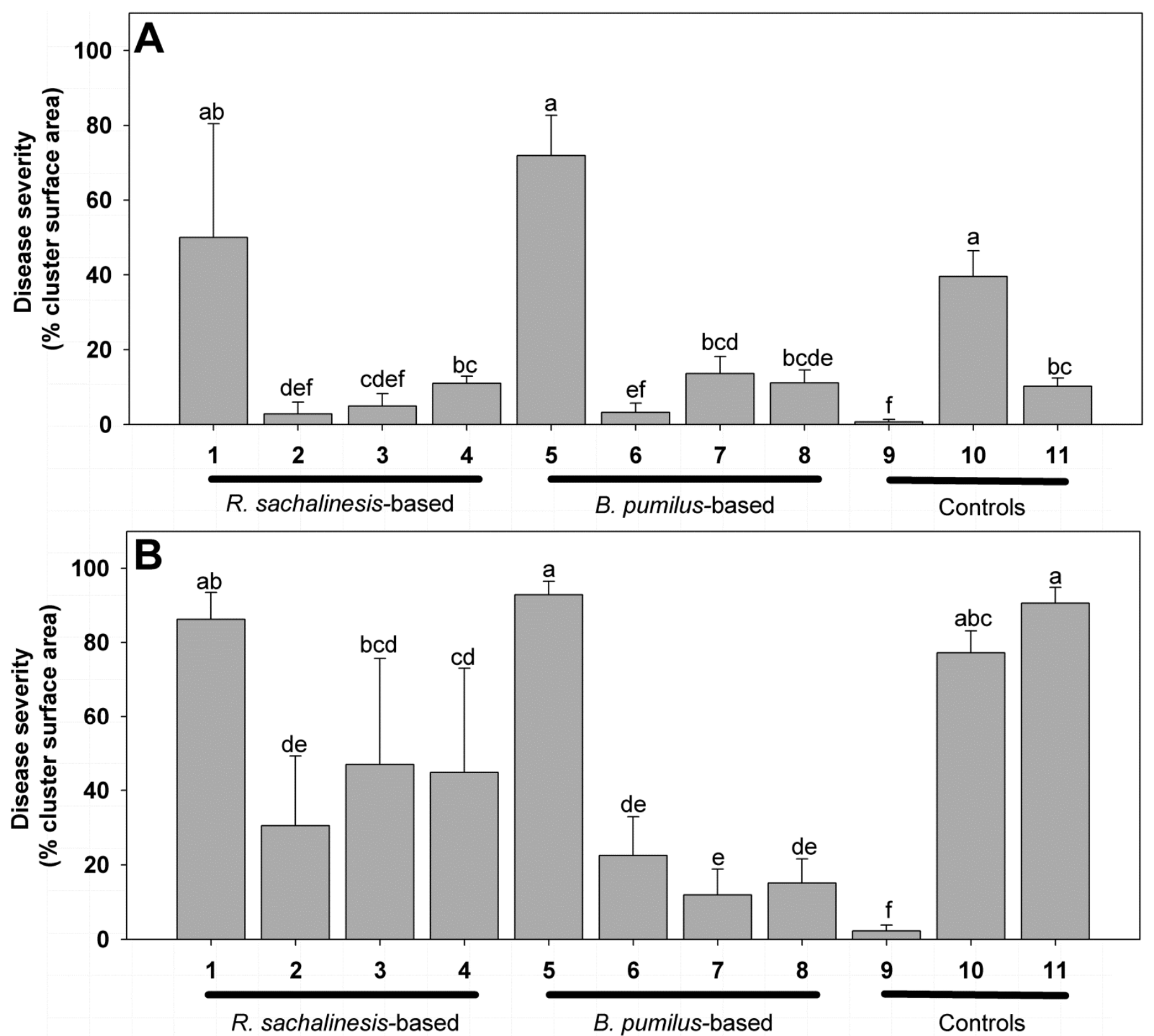

Fungicide program

\section{FIGURE 3}

As described in Table 1, fungicide program significantly influenced final disease severity. In 2013 (A), the young vineyard had variable levels of disease. In one case, the unsprayed control (11) actually outperformed programs that relied on sulfur only (10) and a biopesticide only (5). In 2014 (B), programs that solely relied on biopesticides (1 and 5) had significantly higher disease levels than those that only had one synthetic product applied (4 and 8). Disease data was log transformed prior to statistical analysis; it is presented here as raw severity for ease of interpretation.

In 2014, leaf removal at bloom had significantly lower disease severity overall than the no-leaf-removal control. The prebloom and postbloom leaf removal treatments were intermediary (Fig. 4). While this significant response was seen in the nested analysis of fungicide and leaf removal and was seen when viewing the leaf removal response only, when leaf removal was analyzed within individual fungicide programs, there was no significant difference between leaf removal treatments (Fig. 5). The nested data, however, demonstrated the synergy between the combination of fungicide programs and leaf removal. For example, as a whole, fungicide program 9 (synthetic control) outperformed all other programs, but comparing the means of the combination of leaf removal and fungicide program, prebloom leaf removal in programs 2, 6, 7, and 8, bloom leaf removal in 2, 4, 6, 7, and 8, and postbloom leaf removal in fungicide program 7 all resulted in equivalent disease control relative to all of the leaf removal treatments (and control) in fungicide program 9. This suggests that the optimal timing of early fruit-zone leaf removal in a vineyard is dependent on the chemical choices made for that vineyard. For example, some fungicide programs can be improved in their efficacy when paired with any type of leaf removal (i.e., program 7); the theme in that particular program was the adoption of synthetic products during the critical window of fruit infection. Others benefit from leaf removal before bloom (i.e., programs 2, 6, and 8). Programs 2 and 6, while similar to program 7 , had an additional application of a synthetic product 
just after the end of the critical window, but program 2 also differed in the biopesticide base. Program 8, interestingly, only had one synthetic fungicide application at the very beginning of the period of fruit susceptibility. This program is identical to program 4 in terms of the timing and number of synthetic fungicides, but differed simply in the biopesticide base. Program 4 was enhanced by leaf removal at bloom.

\section{INFLUENCE OF BIOPESTICIDES AND LEAF REMOVAL ON FRUIT QUALITY}

To evaluate soluble solids (Brix), $\mathrm{pH}$, and titratable acidity (TA) in the fruit, five randomly selected whole clusters per fungicide + leaf removal treatment replicate were macerated in a 4-liter plastic zip-top bag. Juice was decanted into a dedicated 50-ml conical plastic centrifuge tube, and was used to determine soluble
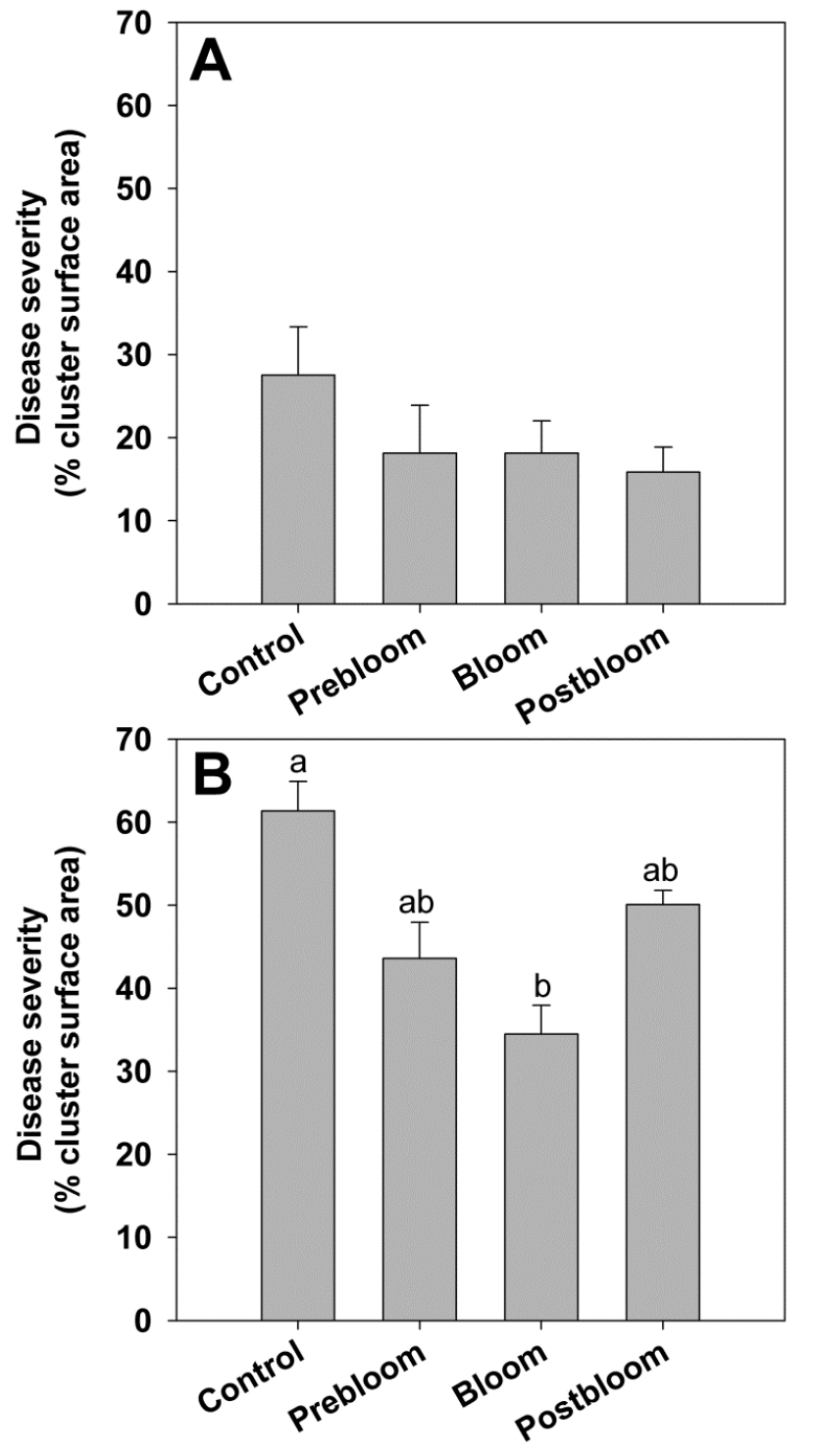

Leaf removal timing

\section{FIGURE 4}

In 2013 (A), leaf removal did not influence overall disease severity. In 2014 (B), however, fruit-zone leaf removal at bloom significantly reduced disease severity relative to the untreated control. Disease data was log transformed prior to statistical analysis; it is presented here as raw severity for ease of interpretation.
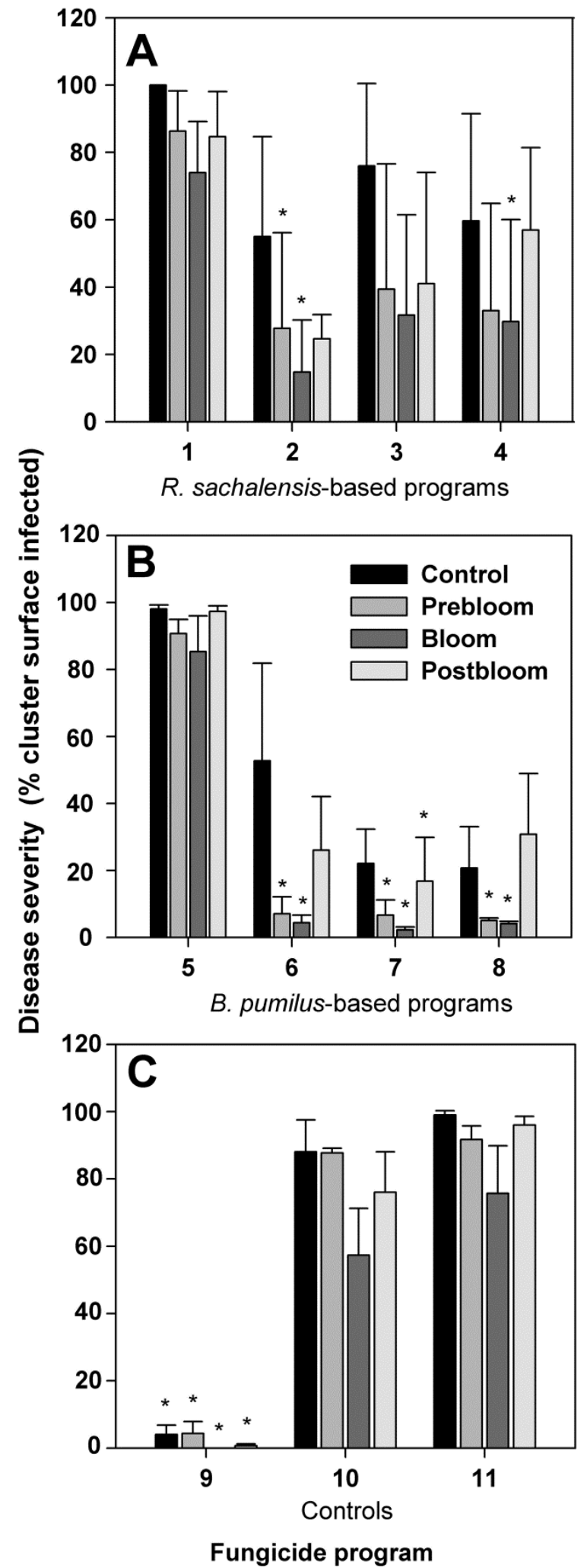

\section{FIGURE 5}

In 2014, leaf removal within a specific fungicide program did not influence overall disease severity in that program. However, when comparing across all leaf removal and fungicide programs, there were instances when leaf removal improved the efficacy of that program to the equivalent of the synthetic-only control (program 9; Fig. 3). Those specific instances are denoted by an asterisk (Tukey's HSD, $a=0.05$ ). (A) $R$. sachalinensis-based programs; (B) B. pumilus-based programs, and (C) controls (synthetic, sulfur, and untreated). 
solids, $\mathrm{pH}$, and TA. Juice soluble solids were measured using a digital refractometer (Quick-Brix 60, Mettler-Toledo,

Schwerzenbach, Switzerland). Juice $\mathrm{pH}$ was measured using a $\mathrm{pH}$ meter (InLab Versatile 413, Mettler-Toledo, Schwerzenbach,

Switzerland). Juice titratable acidity was measured by titrating the sample to a $\mathrm{pH}$ of 8.20 using $0.1 \mathrm{M}$ sodium hydroxide $(\mathrm{NaOH})$ as described by Iland et al. (2000). Fruit was harvested on 6 September 2013 and on 18 September 2014. In both 2013 and 2014, the nested leaf removal treatments did not have an impact on Brix $(P=0.73$ and 0.42 , respectively), TA $(P=0.99$ and 0.15 , respectively), or $\mathrm{pH}(P=0.99$ and 0.61 , respectively). Fungicide program, however, did have a significant impact on Brix between the B. pumilus-based programs in 2013 and 2014, a significant impact on $\mathrm{pH}$ between the $B$. pumilus-based programs in 2013. In addition, the choice of fungicide program also had a significant impact on TA between the synthetic control and the unsprayed control, $R$. sachalinensis-only and B. pumilus-only programs in 2014 (Table 2). Overall, those programs with improved disease control, on average, had harvest quality parameters that were closer to desired levels than those with high levels of disease, which typically had lower soluble solids, higher TA, and higher $\mathrm{pH}$.

\begin{tabular}{|c|c|c|c|c|c|c|}
\hline \multirow[b]{3}{*}{$\begin{array}{l}\text { Fungicide } \\
\text { treatment }\end{array}$} & $\begin{array}{l}\text { uice par } \\
\text { gicide tr } \\
\text { in a colt }\end{array}$ & $\begin{array}{l}\text { TA } \\
\text { meters fo } \\
\text { atments } \\
\text { nn denot } \\
\text { ukey's HS }\end{array}$ & $\begin{array}{l}E 2 \\
2013 \text { ar } \\
\text { found } \\
\text { ignific } \\
\text { at } a=c\end{array}$ & $\begin{array}{l}\text { d } 2014 . \\
\text { in Table } \\
\text { nt diffe } \\
.05 .\end{array}$ & $\begin{array}{l}\text { Descriptio } \\
\text { 1. Letters } \\
\text { ence by }\end{array}$ & \\
\hline & \multicolumn{3}{|c|}{2013} & \multicolumn{3}{|c|}{2014} \\
\hline & $\begin{array}{l}\text { Soluble } \\
\text { solids } \\
\text { ('Brix) }\end{array}$ & $\begin{array}{c}\text { Titratable } \\
\text { acidity } \\
\text { (g/liter) }\end{array}$ & pH & $\begin{array}{l}\text { Soluble } \\
\text { solids } \\
\text { ('Brix) }\end{array}$ & $\begin{array}{l}\text { Titratable } \\
\text { acidity } \\
\text { (g/liter) }\end{array}$ & pH \\
\hline 1 & $21.2 \mathrm{~cd}$ & 7.29 & $3.43 \mathrm{ab}$ & $20.8 \mathrm{ab}$ & $11.33 \mathrm{a}$ & 3.07 \\
\hline 2 & $21.9 \mathrm{bc}$ & 6.80 & $3.40 \mathrm{ab}$ & $20.6 \mathrm{ab}$ & $10.36 \mathrm{ab}$ & 3.05 \\
\hline 3 & $21.6 \mathrm{bcd}$ & 7.84 & $3.40 \mathrm{ab}$ & $20.6 \mathrm{ab}$ & $10.98 \mathrm{ab}$ & 3.04 \\
\hline 4 & $21.1 \mathrm{~cd}$ & 7.39 & $3.39 \mathrm{ab}$ & $20.3 \mathrm{ab}$ & $10.88 \mathrm{ab}$ & 3.03 \\
\hline 5 & $20.9 \mathrm{~d}$ & 7.89 & $3.46 \mathrm{~b}$ & $21.7 \mathrm{a}$ & $11.66 \mathrm{a}$ & 3.06 \\
\hline 6 & $22.1 \mathrm{ab}$ & 7.12 & $3.40 \mathrm{ab}$ & $20.8 \mathrm{ab}$ & $10.92 \mathrm{ab}$ & 3.03 \\
\hline 7 & $21.2 \mathrm{bcd}$ & 7.88 & $3.37 \mathrm{a}$ & $19.4 \mathrm{~b}$ & $10.94 \mathrm{ab}$ & 3.02 \\
\hline 8 & $21.1 \mathrm{~cd}$ & 7.30 & $3.39 \mathrm{ab}$ & $20.8 \mathrm{ab}$ & $10.58 \mathrm{ab}$ & 3.05 \\
\hline 9 & $23.0 \mathrm{a}$ & 7.55 & $3.37 \mathrm{a}$ & $20.5 \mathrm{ab}$ & $9.60 \mathrm{~b}$ & 3.06 \\
\hline 10 & $21.0 \mathrm{~d}$ & 7.11 & $3.40 \mathrm{ab}$ & $21.4 \mathrm{ab}$ & $11.16 \mathrm{ab}$ & 3.06 \\
\hline 11 & $21.1 \mathrm{~cd}$ & 8.11 & $3.39 \mathrm{ab}$ & $20.3 \mathrm{ab}$ & $11.34 \mathrm{a}$ & 3.05 \\
\hline
\end{tabular}

\section{CONCLUSIONS AND RECOMMENDATONS}

When considering the integration of biopesticides into a conventional management program, the timing of those pesticides relative to synthetics in the fungicide rotation should also be considered. Given the temporal window for peak susceptibility of $V$. vinifera berries to infection by $E$. necator (i.e., bloom to 4 weeks postbloom), ensuring that the best available products for disease management are applied during that window is critical. This was seen in our trial results, where programs that integrated as little as one synthetic fungicide during the bloom period had significantly better control than a biopesticide-only or sulfur-only program (Fig. 3). Integrating fruit-zone leaf removal at prebloom or bloom also had the ability to improve the efficacy of disease control of several of the biopesticide-based programs relative to that of the synthetic control program (Figs. 4 and 5). These results highlight the necessity of adding cultural practices such as leaf removal to maintain disease control efficacy when adopting programs that are biopesticide-based.

\section{ACKNOWLEDGMENTS}

We would like to thank Maurisio Garcia for technical assistance and spray application. Funding for the project was provided by the Washington State IR-4 program under a grant titled "The Mitigation of Fungicide Resistance Risk Using Biopesticides in Washington Wine Grapes" and by the Washington State Grape and Wine Research Program under the grant titled "Horticultural Impacts of Fruit Zone Leaf Removal in Wine Grapes and Mitigating Botrytis Bunch Rot in the Winery."

Specific mention and evaluation of commercial products is not indicative of endorsement

\section{LITERATURE CITED}

Abramoff, M. D., Magalhaes, P. J., and Ram, S. J. 2004. Image processing with ImageJ. Biophotonics Int. 11:36-42.

Anonymous. 2016. FRAC code list 2016: Fungicides sorted by mode of action. Fungicide Resistance Action Committee (FRAC), CropLife Int., Brussels, Belgium. http://www.frac.info/publications.

Austin, C. N., and Wilcox, W. F. 2012. Effects of sunlight exposure on grapevine powdery mildew development. Phytopathology 102:857-866.

Carroll, J. E., and Wilcox, W. F. 2003. Effects of humidity on the development of grapevine powdery mildew. Phytopathology 93:1137-1144.

Choudhury, R. A., McRoberts, N., and Gubler, W. D. 2014. Effects of punctuated heat stress on the grapevine powdery mildew pathogen, Erysiphe necator. Phytopathol. Mediterr. 53:148-158.

Copping, L. G., and Menn, J. J. 2000. Biopesticides: A review of their action, applications, and efficacy. Pest Manag. Sci. 56:651-676.

Gadoury, D. M., Seem, R. C., Ficke, A., and Wilcox, W. F. 2003. Ontogenic resistance to powdery mildew in grape berries. Phytopathology 93:547555.

Gadoury, D. M., Seem, R. C., Ficke, A., Wilcox, W. F., and Dry, I. B. 2002. Ontogenic resistance to Uncinula necator in grape berries: Impacts upon the pathogen, disease progress, and management of powdery mildew. Proc. The 4th Int. Workshop on Powdery and Downy Mildew in Grapevine. D. M. Gadoury, et al., eds. Univ. of Calif., Davis.

Iland, P. G., Ewart, A., Sitters, J., Markides, A., and Bruer, N. 2000. Techniques for chemical analysis and quality monitoring during winemaking. Patrick Iland Wine Promotion, Cambelltown, South Australia.

Jacobsen, B. J., Zidack, N. K., and Karson, B. J. 2004. The role of Bacillusbased biological control agents in integrated pest management systems: Plant diseases. Phytopathology 94:1272-1275.

Leavitt, G. M., and Martin-Divall, T. M. 2005. Powdery mildew control study in Carignane grapes in the San Joaquin Valley of California, 2004. Fungicide and Nematicide Tests 60:SMF002. doi:10.1094/FN60.

Moyer, M., and O’Neal, S. 2014. Pest Management Strategic Plan for Washington State Wine Grape Production. Office of Pest Manage. Policy, USDA Nat. Inst. of Food and Agric. http://www.ipmcenters.org/pmsp/pdf/ WA_WineGrape_PMSP_2014.pdf.

Moyer, M. M., Gadoury, D. M., Wilcox, W. F., and Seem, R. C. 2016. Weather during critical epidemiological periods and subsequent severity of powdery mildew on grape berries. Plant Dis. 100:116-124.

Schilder, A. M. C., Gillett, J. M., and Sysak, R. W. 2010. Evaluation of fungicides for control of powdery mildew and downy mildew in wine grapes, 2008. PDMR 4:SMF034. doi:10.1094/PDMR04.

Wilcox, W. F., and Riegel, D. G. 2010. Evaluation of fungicide programs for control of powdery mildew on Rosette grapes, 2009. PDMR 4:SMF055. doi:10.1094/PDMR04.

Wilcox, W. F., and Riegel, D. G. 2012. Evaluation of fungicide programs for control of grapevine powdery mildew, 2010. PDMR 6:SMF049. doi:10.1094/PDMR06. 